International Journal of Engineering \& Technology, 7 (2.29) (2018) 1069-1071
International Journal of Engineering \& Technology
SPC
Website: www.sciencepubco.com/index.php/IJET
Research paper

\title{
Reliability index of critical thinking among electrical technology teachers
}

\author{
Mohd Hizwan Mohd Hisham¹, Yusri Kamin¹, Muhammad Sukri Saud ${ }^{1}$ \\ ${ }^{1}$ Department of Technical and Vocational Education, Faculty of Education, Universiti Teknologi Malaysia \\ *Corresponding author E-mail: hizwanhisham@gmail.com
}

\begin{abstract}
This paper aims to determine the reliability index for critical thinking among electrical technology teachers in vocational colleges. Teachers are the backbone of the education system in technical education and the executor of the policies and goals that have been set by the government through the Ministry of Education. Critical thinking is one of the higher order thinking skills that involves both cognitive skills and dispositions. Empirical research suggest that people begin developing critical thinking at a very young age. Teachers are thus urged to provide explicit instruction in critical thinking to teach how to transfer knowledge critically to students. In order to transfer critical thinking, the teacher should be infused with the sub-skills that contribute to the development of critical thinking.
\end{abstract}

Keywords: Critical Thinking, Electrical Technology, Teacher.

\section{Introduction}

Vocational college teachers should understand that critical thinking changes lives by helping students learn to recognize, analyze and evaluate arguments which can provide them with the foundation to successfully complete their study and become more engaged Malaysian citizens [1].

Critical thinking is very useful during learning because students will learn to recognize, analyze and evaluate arguments [1]. In vocational colleges, a teacher must be able to demonstrate knowledge and comprehension of subjects, and at the same time employ higher cognitive skills such as application, analysis and synthesis instead of memorizing pertinent information to be repeated in the final exam or written in a book. Instead, a teacher must dismantle the information and apply them in new ways and to new problems $[2,3]$.

\section{Problem statement}

One report [4] has shown that teachers in Malaysia lack higher order thinking skills. This is supported by the Malaysian Education Blueprint 2013-2025 which stated that teachers in Malaysia should improve their higher order thinking skills in order to teach students more effectively [5]. Currently, teachers in Malaysia only have moderate skills regarding higher order thinking [6].

Despite the wider range of studies conducted to understand more about higher order thinking skills in technical and vocational education, authors that reviewed previous studies on higher order thinking skills agree that there is still a gap in the application of higher order thinking skills among teachers when teaching [7]. Most teachers nowadays are not able to deliver higher order thinking skills such as critical thinking to unfamiliar scenarios and are not able to justify every action that they take in the process of solving problems [8]. Therefore, developing critical thinking among vocational teachers in electrical technology is essential to maximize their thinking skills.

\section{Critical thinking}

Many educators believe that critical thinking is the most important cognitive skill to be mastered [9]. One researcher defined it as "reflective and reasonable thinking that is focused on deciding what to believe or do". To him, it involves:

i. The ability to define and clarify things as problems, issues, conclusions, reasons, and assumptions.

ii. The ability to judge the credibility, relevance and consistency of information.

iii. The ability to infer or solve problems and draw reasonable conclusions.

Some researchers and scholars [10] use the terms 'critical thinking' and 'higher order thinking' interchangeably, while others define critical thinking as a form of higher order thinking. Some use the term 'critical thinking' as a form of higher order thinking. Some use the terms 'critical thinking' and 'problem solving' interchangeably and some say that critical thinking is a form of problem solving. Critical thinking is a domain that has to be defined in detail through Gubbins's Matrix of Critical Thinking. Critical thinking can be explained in the following ways [11]:

1. Critical thinking includes goal directed, reflective and reasonable thinking to evaluate the evidence for an argument for which all the information may not be available. 
2. An essential component in the metacognitive process.

3. An analysis, inference, interpretation, explanation and self-regulation, systematic, analytical, judicious, truthseeking, open-minded and confident disposition towards the critical thinking process.

\section{Research Objective}

There are two objectives for this study, which are:

1. To determine the reliability index of critical thinking items.

2. To determine the separation index of the critical thinking items.

\section{Methodology}

It is very important for the researcher to understand the underlying philosophy of the research. This is so the researcher will be able to adopt the most appropriate techniques and approaches in the research methods [12]. The definition of a research design is to describe the general procedure for carrying out scientific research, as well as guiding the research procedure to gather, analyze and interpret data [13]. The research design will help the researcher to obtain information and ensure the objective of the study is achieved. Choosing an appropriate research approach is thus critical for any researcher who intends to conduct any type of research [14]. In this light, this study aims to obtain feedback on the application of higher order thinking skills gained through teaching and learning approaches.

This study employed the quantitative approach. Quantitative research is used based on the understanding that the amount of observable facts in a research can be described based on the parameter of its quantity [15]. In this study, the quantitative method was used to describe the data collected from a structured questionnaire (data collection instrument).

Rasch Model Analysis

The measurement in an instrument's development process is important because it affects the research in many ways. The Rasch model of analysis has been proven as an excellent measurement by many researchers around the globe [16]. The measurement is referred to as a process with the aim to discover ratios rather than assigning numbers [17]. There is an increasing number of research that used the Rasch model of analysis in the development of instruments and to validate the instrument, especially in the context of providing evidence of validity and reliability of the constructs being measured [18].

By using the Rasch model of analysis, it allows the researcher to comprehend several measurement issues such as the requirement of variant measurements. For example, the ratio of difficulties between any pair of the items remains constant across the ability levels of the respondents. By using the Rasch model of analysis, the researcher is also able to determine the requirement for the validity of transformation to interval scaling, check whether or not the category ordering of polytomous items works as expected by the researcher, and check whether the item differential function is biased among subgroups in the sample. In designing the questionnaire, it is often that the ordinal score will be summed up [19]. Because of this, the Rasch model of analysis is the best to test the internal construct validity of the scale for unidimensionality identification. By using the Rasch model of analysis, the researcher may also demonstrate the relationship between difficulty and person's ability. The latent variable is conceptualized as existing along a continuum. The items in the questionnaire can then be hierarchically ordered along the continuum. The results provided by the Rasch model of analysis is thus specific on the continuum [20].

In this study, 120 teachers who teach electrical technology in vocational colleges across Malaysia were selected to be the respond- ents. Fourteen sub-skills [21] which were identified as contributing to the development of critical thinking were tested. The fourteen sub-skills were:

1. Analyse arguments

2. Provide explanation

3. Give logical reason

4. Convincing

5. Drawing conclusion

6. Making prediction

7. Differentiate between facts and opinion

8. Proposing solution

9. Relating between cause and effect

10. Provide cause

11. Deep understanding

12. Curiosity

13. Questioning

14. Development of knowledge

During instrument testing, the respondents needed to give their opinions on how these fourteen sub-skills were important in developing critical thinking among them. The respondents were asked to rate their opinions according to a five-point Likert scale.

\section{Results}

The value for person reliabililty was 0.83 with the person separation index of 2.21. The person separation index value showed that there were two levels of person ability that could be categorized by the instrument. Figure 1 shows the person reliability and person separation for critical thinking skills.

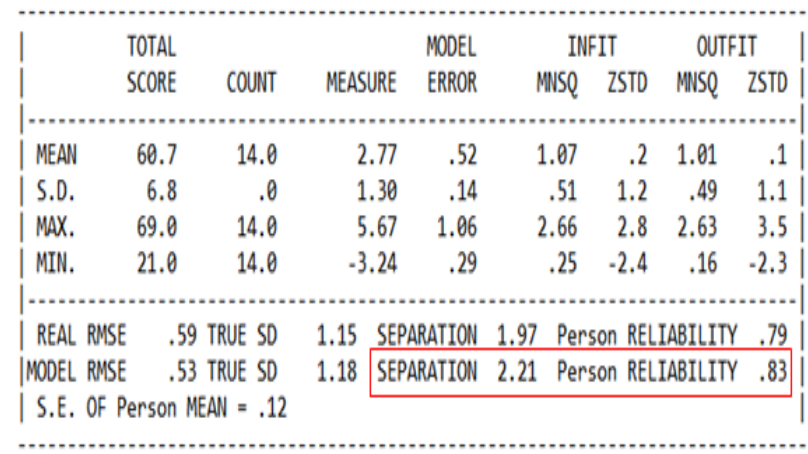

Fig. 1: Person Reliability \& Person Separation

On the other hand, the index of items reliability for creative elements was 0.91. As for the items separation, there were three levels which produced the separation index of 3.09. This means that there are three level of difficulties across all the items. Figure 2 shows the item reliability and item separation for critical

\begin{tabular}{|c|c|c|c|c|c|c|c|c|c|}
\hline & \multicolumn{2}{|l|}{ TOTAL } & & \multirow{2}{*}{$\begin{array}{l}\text { MODEL } \\
\text { ERROR }\end{array}$} & \multicolumn{3}{|c|}{ INFIT } & \multicolumn{2}{|c|}{ OUTFIT } \\
\hline & SCORE & COUNT & MEASURE & & & MNSQ & ZSTD & MNSQ & ZSTD \\
\hline MEAN & 523.5 & 120.0 & .00 & .17 & & .98 & -.3 & 1.01 & -.3 \\
\hline S.D. & 23.6 & .0 & .55 & .01 & & .42 & 2.4 & .53 & 2.5 \\
\hline MAX. & 546.0 & 120.0 & 1.66 & .19 & & 2.37 & 7.2 & 2.85 & 8.0 \\
\hline MIN. & 447.0 & 120.0 & -.64 & .13 & & .72 & -2.0 & .71 & -2.0 \\
\hline REAL & & RUE SD & .52 & RATION & 2.95 & Item & & ABILITY & .90 \\
\hline MODEL & & TRUE SD & .52 & ARATION & 3.09 & Item & & IABILITY & .91 \\
\hline
\end{tabular}

Fig. 2: Item Reliability \& Item Separation 


\section{Discussion}

The role of the teacher today goes beyond only teaching in the class as they also need to implement higher order thinking skills into their lessons to produce more productive citizens in the future. The findings from the quantitative study demonstrated that to develop critical thinking among teachers, there are several subskills that are important to be equipped. Teachers need to actively and skillfully conceptualize the electrical technology content. Aside from that, a critical electrical technology teacher should be able to apply the electrical technology concepts from the textbook into real life situations. Thus, the explanation towards students regarding electrical technology becomes more vivid as the teacher can relate well the concepts that they teach in the classroom into real-life situations [22]. An electrical technology teacher must also be able to analyze the information regarding the subject matter. A critical electrical technology teacher can use his/her prior knowledge to examine the different viewpoints on issues concerning the impact of electrical technology on everyday life and evaluate the issues from the student and society's perspectives.

Person: REAL SEP.: 1.97 REL.: .80 ... Item: REal SEP.: 2.95 REL.: .90

Item STATISTICS: CORRELATION ORDER

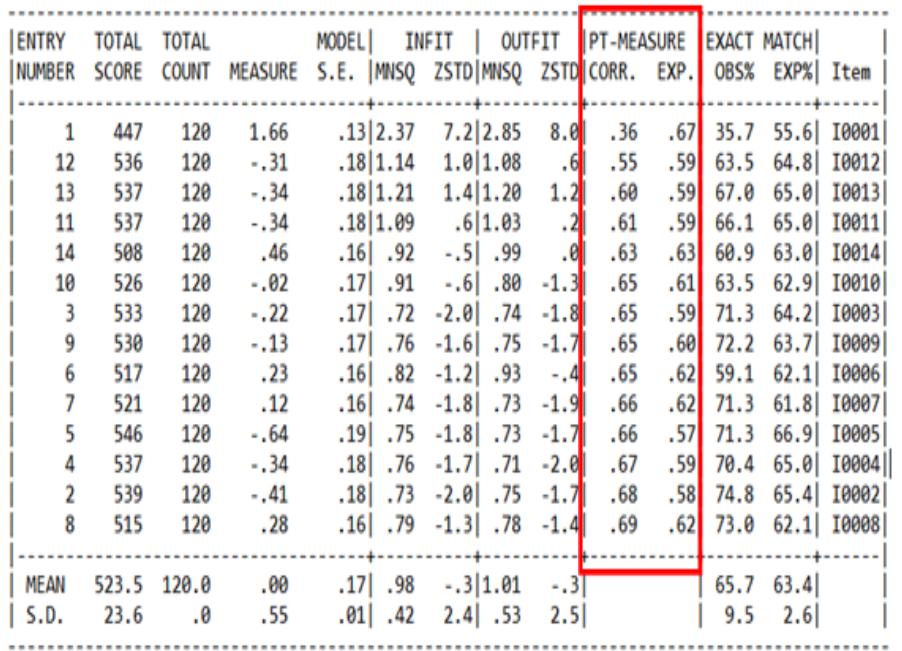

Fig. 3: Item PT-Measure Correlation

Figure 3 shows the PT-Measure correlation in measuring the subskills that contribute towards the development of critical thinking. Based on the results, it shows that all sub-skills are needed in developing critical thinking except for item I001 which was 'analyzing arguments'. The item needed to be deducted because the point measure correlation was not in the range between $0.4-1.4$ [23]. Items I002, I003, I004, I005, I006, I007, I008, I009, I010, I011, I012, I013 and I014 were highly accepted and showed good reliability above 0.8 and good separation index which had three difficulties across all the items and was also valid in the PT- Measure correlation of between $0.55-0.69$.

\section{Conclusion}

In conclusion, in developing critical thinking among teachers who teach electrical technology in vocational colleges, thirteen subskills are needed to be adapted. Thus, the items that were accepted in developing critical thinking among electrical technology teachers are:
1.
Provide explanation
2. Give logical reason
3. Convincing
4. Drawing conclusion
5. Making prediction
6. Differentiate between facts and opinion
7. Proposing solution
8. Relating between cause and effect
9. $\quad$ Provide cause
10. Deep understanding
11. Curiosity
12. Questioning
13. Development of knowledge

It is expected that the findings from this study will be a guide and reference for the electrical technology teachers in enhancing their critical thinking skills and help them in future teaching and learning sessions.

\section{References}

[1] Jackson D \& Newberry P (2012), Critical Thinking: a user's manual. Wadsworth/Cengage Learning, Boston.

[2] Bloom BS (Ed.) (1956), Taxonomy of educational objectives: The classification of educational goals. New York: Longmans, Green.

[3] Anderson LW \& Krathwohl DR (Eds.) (2001), A taxonomy for learning teaching and assessing. New York: Longman.

[4] Ruslan M \& Nyet MS (2016), The Development And Validation of A Thinking Map-Aided Problem Based Learning Module For Physical Science Theme of year 5 Science. International Journal of Current Research 8(33780-33786), Issue, 06 June, 2016.

[5] Ministry of Education Malaysia (2013), Malaysia Education Blueprin 2013 - 2025. Education 1-268

[6] Nor Hasmaliza H \& Zamri M, PERSEPSI GURU Bahasa Melayu Sekolah Menengah Terhadap Kemahiran Berfikir Aras Tinggi, Jurnal Pendidikan Bahasa Melayu -Jpbm (Malay Language Education Journal -MYLEJ) 6(2), 2180-4842. (NOV. 2016): 78-90.

[7] Selvadurai, Sivapalan, Choy, Er Ah, Maros \& Marlyna. (2012), Generic Skills of Prospective Graduates from the Employers' Perspectives. Asian Social Science 8(12), 295.

[8] Sean R, Cathy-Ann R, Jeevan, P \& Daaniel R (2014), Use of Argument Maps to Promote Critical Thinking in Engineering Education. IEEE

[9] Jones JM \& Safrit D (1994), Developing Critical Thinking Skills In Adults Learner Through Innovative Distance Learning. International Conference on the Practice of Adult Education and Social Development.

[10] King FJ, Goodson L \& Rohani F (2013), Higher order thinking skills. Center for Advancement of Learning and Assessment. Retrieved from: http://www.cala.fsu.edu/files/higher_order_thinking_skills.pdf.

[11] Crowl TK, Kaminsky S \& Podell DM (1997), Educational Psychology: Windows on Teaching. Madison, WI: Brown and Benchmark

[12] Siti Uzairah MT (2013), Research Methodological Cage: Understanding the Qualitative Viewpoint (January 2013). Kuala Lumpur: ARAS Publisher. ISBN: 978-967-11662-0-8

[13] Nornazira S (2016), Competencies Framework for Culinary Profession in Malaysian Hotel Sector. Doctor of Philosophy Thesis. Universiti Teknologi Malaysia.

[14] Plano-Clark VL \& Creswell JW (2010), Understanding Research: A Consumer's Guide. Merrill, Boston

[15] Kothari CR (2009), Research Methodology: Methods \& Techniques" (Second Revised Edition), New Age International Publishers, New Delhi.

[16] Carvalho LDF, Primi R \& Meyer GJ (2012), Application of the Rasch in measuring personality disorders. TIPP 34(2), 101-109.

[17] Ewing MT, Salzberger T \& Sinkovics RR (2005), An alternate approach toassessing cross-cultural measurement equivalence in advertising research. Journal of Advertising 34(1), 17-36.

[18] Zhang Q \& Zhang T (2015), Rasch Model: Status Quo \& Prospect in China. (PROMS) 2014 Conference Proceedings.

[19] Prieto L, Alonso J \& Lamarca R (2003), Classical test theory versus Rasch analysis for quality of life questionnaire reduction. Health and Quality of Life Outcomes 1(1), 27.

[20] Bond T \& Fox C (2007), Applying the Rasch model: Fundamental measurement in the human sciences (2nd). Mahwah, NJ: LEA.

[21] Rajendran NS (2016), Teaching \& Acquiring Higher Order Thinking Skills. Theory \& Practise. Penerbit Universiti Pendidikan Sultan Idris.

[22] Nik Hanis Zuraihan Rahimi, Abdullah Mat Rashid \& Ramlah Hamzah (2015), Hubungan Antara Penglibatan Dalam Pembelajaran Dengan Tahap Pemikiran Reflektif Dalam Kalangan Pelajar Pendidikan Teknikal Dan Vokasional. Journal of Human Capital Development Habitual. ISSN 8(1), 1985-7012 January - June 2015.

[23] Linacre JM (2002), What do Infit and Outfit, Mean-square and Standardized mean? Rasch Measurement Transactions 16(2), 878. 